\title{
Søren Kierkegaard og Nordslesvig.
}

\section{Af Carsten Petersen.}

Blink i det Fjerne. Smaa, hurtige Blink; naaske et Marsvin, der tumler sig i Bølgerne. Folk ved Stranden gør hinanden opmærksomme paa det og gaar videre.

Men ude over Synsranden danner sig en mork Plet, den vokser og nærmer sig. Vejrprofeterne betragter deres fine Redskaber og sporger: Er der UTvejr i Vente?

Ja, der er Uvejr i Vente. Det er ikke Marsvin i Lillebælt, men Lyn og Torden. Et Guds Vejr, som det kommer nu og da i denne Verden, drager op over Haderslev By. Det kan koste Liv og Menneskelykke.

Sisren Kierkegaard har rejst sit Angreb mod Danmarks Førstebiskop, den fødte Slesviger H. L. Martensen. Snart efter har han udvidet Angrebet til hele Fæstningen, den danske Præstestand og den danske Folkekirke. Han, den ene, den enkelte, uden Parti, uden Skole, uden Hær stormer mod Kirkens gamle Mure med den Magt og Myndighed, som alene Sandhed og Redelighed kan give. Fæstningen faldt ikke, og ingen faldt i den, kun Belejreren selv segnede i Døden. Men inde i Fæstningen oplevede man Angsten under Uvejret. Visse Livets Grundspørgsmaal og Grundforhold blev i de Dage efterset paany.

Hen over Haderslev drog Uvejret. Her var nok at slaa ned i: Den gamle Domkirke, uden Taarn men dog højere end noget andet Hus i Staden; den lærde Skole, pro patria et litteris stod der paa dens Pande, "for Fædreland og Videnskab", ny opstaaet efter Krigen 1848-50, et Arnested for dansk Aandsliv; det unge Dannevirke, Dagbladet fra Papegøjegaden, tilhuse i en ringe Bygning, men fuldt af Sprængstof som et Krudtmagasin.

Her var nok at tænde i, Mænd og Kvinder med aabne Øjne og stærke Sind, med Mod og Vilje, Temperament og Fatteevne, Tænkere, Digtere, Videnskabsmænd: Rektor Søren Bloch Thrige og hele hans Stab, deriblandt Joh. Fibiger, J. Aschelund, 
Ed. Lenibcke, Prasterne H. P. Kofoed-Hansen og Fr. Helweg, Redaktøren P. C. Korh, og lige uden for Byens Porte Præsterne Hertel, Bojsen, Marckmann o. a. - Navne, som allesanmen staar skrevne i Danmarks Historie.

To af de her næunte Mænd var fortrolige med s. Kierkegaard og stærkt prægede af hans Ideer længe før det sidste stærke Røre begyndte, nemlig H. P. Kofoed-Hansen og Joh. Fibiger.

Hans Peter Kofoed-Hansen er et af de faa Mennesker, i hvem de Kierkegaard'ske Tanker genspejler sig i stille Klarhed og dyb Oprigtighed. Med en tilbageholdende Fornemmelse, næsten som stod man over for et "Rør mig ikke«, griber man Penuen for at skitsere hans Billede. I Kirkebøgerne i sit Provsti har han skrevet sit Navn med klare, rolige Træk, dog ikke uden Sving, som den der kender Livet fra sig selv, fra sit Hjertes dybe Kilder, og derfor ikke trænger sig ind paa andre. I sine Bøger er han den rolige og ubestikkelige Iagttager og dog aldrig ubevæget. Af skum er der kun lidt, men Brændingen er der alligevel. Svenskeren W. Rudin, da han skulde skrive sin Bog om Søren Kierkegaards Person og Forfatterskab, kom først til $\mathbf{H}$. I'. Kofoed-Hansen og blev hos ham i otte Dage, og dette Samvær har uden Tvivl været medvirkende til, at denne Bog er blevet et sjældent smukt Mindesmærke om S. K. I det Hele taget erkender man ved at gennemvandre den omfangsrige Kierkegaardlitteratur mere og mere, hvor vanskeligt det er for de forskellige Forfattere, at naa ind til Nerven uden at blotte den. Thi der er noget ved denne sælsomme Tænker, som kun maa iagttages gennem det Svøb, hvori det ligger; det taaler ikke, at afklædes med kolde spidse Fingre. Kun faa, meget faa, har haft den Sindets.Grebethed og den Sprogets Nænsomhed til at tale om deres Emne som W. Rudin og H. P. Kofoed-Hansen.

Som Adjunkt ved Odense Katedralskole blev H. P. KofoedHansen snart Medlem af og derefter Sekretær for Fyens Stifts literære Selskab. Samtidigt opstod i ham Trangen til selv at udrede sine Tanker i Bogform. Under Navnet Jean Pierre (= Hans Peter) udgav han 1840: Dialoger og Skizzer. Af en Phy- 
siognoms efterladte Papirer udgivne af Jean Pierre -- 1842: Liv af Død. En Fortælling af Jean Pierre - 1845: Kød og Aand eller de to Veje. En Sjælehistorie af Jean Pierre.

Men i Aaret 1843 udkom "Enten - Eller, Et Livsfragment af Victor Eremita«, den første i den lange Række af Bøger, som s. Kierkegaard udsendte under forskellige paatagne Navne. Af denne Bog, som vel er og bliver noget Enestaaende i den danske Bogverden, blev Adjunkten stærkt grebet, og inden Aaret var omme, havde han skrevet en meget udførlig og indgaaende Anmeldelse $\mathbf{i}$ "For Literatur og Kritik. Et Fjerdingaarsskrift udg. af Fyens Stifts lit. Selskab.“ Forfatteren aabenbarer sig i dette Arbejde som en af de første i Danmark, der med fuld Forstaaelse opfattede det fremsatte Enten - Eller, for saa vidt en Læser dengang allerede kunde sætte sig ind i S. Kierkegaards Hensigter. Fra den Stund af har Adjunkten sikkert fulgt den nye Tænker med den stille Lidenskab, som S. K. ønskede at finde hos sin Læser.

I Odensetiden oplevede den unge Mand ifølge sine egne efterladte Optegnelser nogle tunge Skuffelser - "Jeg har tidligt bildt mig ind at kende Livets Smerter", skriver han - og disse Erfaringer maa det vel tilskrives, at han, som af Naturen var ilter og havde et heftigt Væsen, blev mere modtagelig for det Ulystvækkende og Neddæmpende, vel ogsaa for den Ironi, som han mødte i Søren Kierkegaards Skrifter.

Efter at have været Præst i Kristianshavn et Aars Tid flyttede han i 1850 til Haderslev og blev her Hovedpræst ved Vor Frue Kirke. Aaret efter viedes han i Odense til Komtesse Sophie Isabella Lætitia Moltke. I 1855 lod han sig forflytte til Gammelhaderslev. Fra 1854 havde han tillige overtaget Provsteforretningerne.

Et personligt Bekendtskab og Venskab mellem S. Kierkegaard og H. P. Kofoed-Hansen var allerede opstaaet i Fyrrerne. Da sidstnævnte rejste til Slesvig, sagde han mundtligt Farvel til S. K., og da sagde denne: "De vil Intet høre fra mig en Tid, men saa vil De atter høre fra mig «, hvormed han sigtede til sit sidste, forestaaende Angreb i "Øjeblikket«, der først kom fire Aar se- 
nere. Men om det indbyrdes Samkvem har S. K. paa sin egen Maade givet Besked i et Brev, som var tiltænkt Vennen, men aldrig blev afsendt. Udkastet fandtes $i$ hans Papirer og indeholder bl. a. følgende Sætninger: "Dersom De levede i København, vilde jeg formodentlig en Dag realisere en længe paatænkt Plan. - Ak, thi der synes at være en Skæbne over Udførelsen af de længe paatænkte Planer.... at aflægge et Besug. hilse paa Den og Den .... Altsaa, dersom De levede i København, havde jeg formodentligen ved Hjælp af et Indfald taget Sagen paa tvært og var kommen hovedkulds ind af Døren til Dem. Muligen var jeg da endog falden ind af Døren og havde raabt med Ugelspegel: det Hastværk har Fanden skabt! De veed formodentligt, at der fortælles om U., at han blev sendt $i$ Byen af hans Madmoder for at købe en Pægel Vin, at han derpaa udeblev i \& Aar, indtil han en Dag kom styrtende ind $i$ Stuen, faldt og slog Flasken i Stykke og raabte: Det Hastværk har Fanden skabt.

Men da De nu ikke bor i København, saa maa jeg gøre noget andet: nemlig ved $\mathrm{Hj}$ ælp af et Brev se at realisere en længe paatænkt Plan. Skønt jeg nemlig (netop for ganske og ganske konsekvent at kunne tilhøre den Idee, hvilken jeg har den Ere at tjene) kun saare lidet indlader mig med noget Menneske, ja endog undgaar enhver Forbindelse, saa følger deraf ingenlunde, at jeg forbliver uvidende om, hvad der sker om mig, ej heller at jeg, uden Sympati og uden villig Anerkendelse af virkelig Dygtighed, erfarer, hvad der tildrager sig. Netop i denne Anledning har jeg oftere tænkt paa Dem, og tænkt paa, under hvor utaknemlige Vilkaar De arbejder som Forfatter.

Som det da er Skik og Brug og ret hensigtsmæssigt, at Soldaterne paa de farefulde Poster i Nattens Morke engang imellem raaber til hinanden, saaledes onsker jeg dette lille Brev fra min Side betragtet som et Tilraab, og skal det glæde mig, on det er Dem kært, at der raabes saaledes.

... Det har ogsaa glædet mig, at der dog endeligt kom en Anmeldelse af Deres »Kød og Aand«, en udførlig, en velvillig. - For mig har denne Anmeldelse tillige betydet noget andet, thi 
det har mindet mig om, hvad jeg ikke vil kalde en længe paatænkt Plan, men dog et Ønske, jeg har haft, selv at anmelde denne Bog. Det havde jo $\mathrm{i}$ en vis Forstand kun været Gengæld, Lige for Lige, - men jeg haaber, at dog ogsaa et Venskab kan holde uden dette nøjagtige Lige for Lige.

... jeg har i disse Dage holdt Fyraften og derved faaet Tid til Et og Andet, og har jeg bestandigt haft in mente, at et Tilraab til Dem horte med dertil.

\section{Venskabeligst}

S. Kierkegaard."

I Haderslev var det saa, at Uvejret kom, det Uvejr, hvis stærkeste Udladninger knyttede sig til S. Kierkegaards Død. Joh. Fibiger i "Mit Liv og Levned" siger derom: "Bevægelsen i Haderslev blev saa stærk, at det kunde kaldes en aandelig Revolutionstid. Byens Redaktør forkyndte stadig i sit Blad, at Kirkens sidste Tider var komne; vor Provst pakkede ind for at gaa ud af Kirken, og en ung Skolelærer samlede hveranden Aften en vrimlende Mængde $i$ et meget stort Lokale, og udmyntede for Almuen med profetisk Talestrøm Kierkegaards groveste Varer. De Troende saa forfærdede paa hinanden, de havde dog ment, at de var Christne, og de Vantro gik i Klubben og gjorde Vittigheder om de Præster, hvis Præk man nu skulde nyde fuld Frihed for, al den Stund det var en Forbrydelse at gaa i Kirke, en Forbrydelse, man iøvrigt vidste sig godt nok fri for."

Vi maa nu et Øjeblik forlade den Mand, hvis Liv og Tænken vi har søgt at sætte os en Smule ind i, for at kaste et Blik paa de Tilstande, der er belyst $i$ ovenstaaende Erindringer af en Person, som selv stod midt i Begivenhederne.

Vi griber Avisen. Peter Kristian Koch er Redaktør af "Dannevirke«, en begavet, ilter og foretagsom Person. Alt, hvad der gnistrer i denne Verden, giver Genblink i hans Øjne. Og han gaar ikke længe og bærer paa Hemmeligheder. Ind i Avisen med det, ud i Folket med det - lad det knalde, futte og bruse.

I de københavnske Aviser læser han om Sandhedsvidnestriden. Var Biskop Mynster et Sandhedsvidne [som H. L. Mar- 
tensen havde kaldt ham], et af de rette Sandhedsvidner - er dette Sandhed? (Art. af S. K. i "Fædrelandet«). Fluks genlyder let $\mathbf{i}$ "Dannevirke«: "Medens Ordføreme $\mathrm{i}$ denne Mangde raaber, at S. K. er gal, kan det gerne hæncles, at han derved la- der sig virkelig skræmme og i Stedet for at vedblive at oplyse Forholdene "priser Tavsheden".

"Dannevirke«-Redaktøren sidder uroligt paa sin Stol. Bare ikke Tavshed! Men han kender ikke S. Kierkegaard. Lade sig skræmme? Nej, som en Kæmpekanon afgiver sine visse bestemte jordrystende Skud, saadan kommer i regelmassige Mellemrum, med fast og roligt sigte de Kierkegaardske Granater, tilsidst det velkendte Sprængstof i Bladrækken "Øjeblikket“.

»Dette skal siges - saa være det da sagt«. Hvilket? Dette: Hvo du end er, hvilket dit Liv forresten, min Ven, - ved (hvis du ellers deltager $i$ den) at lade være at deltage $i$ den offentlige Gudsdyrkelse, som den nu er (med Paastand paa at være det nye Testamentes Kristendom) har du bestandig een og en stor Skyld mindre, Du deltager ikke i at holde Gud for Nar veil at kalde det nye Testamentes Kristendom, hvad der ikke er det nye Testamentes Kristendom.

Og dette: Det Spørgsmaal om hvad Kristendom er, og dermed igen Sporgsmaalet om Statskirke, Folkekirke, hvad man nu vil kalde det, Sammensmeltningen eller Sammenhollet af Kirke og Stat skal bringes til den yderste Afgørelse.

Og dette: Jeg tør ikke vige, mig tvinger en højere Magt, der vistnok giver Kræfter, men ogsaa ubetinget vil lystres, ubetinget, blindt som Soldaten Commandoen, om muligt med det Uvilkaarliges Præcision, som Rytter-Hesten lystrer Signalet.

Det er de første Signalskud i København. Dermed er ogsaa "Dannevirke" mobiliseret. P. C. Koch begynder at forstaa.

I Nr. 11 af Aargangen 1855 er en Artikel af "Sjællandsposten « aftrykt, som giver S. K. Ret $i$, at Biskop Mynster ikke var en særlig fremragende Kristen. Han deklamerede paa Prædikestolen og elskede de fine Nydelser. Noget senere gengives en Artikel om Præsterne: de ere ofte brave Mennesker, men des- 
uagtet langt mere Agerdyrkere, Studefedere, L'hombrespillere og Tobakssmogere end den kristne Religions Tjenere.

Og nu holdes Laserne noje underrettede om alt, hval der passerer i denne Sag, ja, vi mærker snart, at P. C. Koch har faaet sig en særlig Meddeler i Hovedstaden, som hastigst skal forsyne "Dannevirke" med Udpluk af de kierkegaardske Artikler. Inder dette Forspil døde Præsten i Ganmelhaderslev, Provst Janssen, P. C. Koch's sognepræst. Om han var en L'hombrespiller og Tobakssmager, vides ikke, men i Indberetninger paa Embedsvegne er han blevet karakteriseret som en Mand, hos hvem aandelig Folle ikke var at faa. Ogsaa haus Navn hvirvledes ind i "Dannevirke«s Spalter og fik sit Besyv, modsagt af Degnen, der mente at skulle værne om sin Foresattes Eftermæle.

Et nyt Navn glider os forbi: Skolelæyer M. Sommer. Vi har hort det engang for. Ifjor henimod Jul skrev samme skolelærer en Adventssalme til "Dv.«, uden Oprorstoner og Hanegal, en rigtig kon lille Salme. Nu siges der, at han holder kristelige Katekisationer $\mathrm{i}$ sin skole, hvor ikke blot Børnene faar deres Søndagsopbyggelse, men hvor ogsaa Voksue er tilstedle i Hundredevis. Kan han komme godt fra det, har man hørt sige, saa giver han Prasterne Dask, dog ikke naar nogen af dem er tilstede. Peter Kristian Koch syues godt om dette. Uide i Landet gaar ogsaa Snakken imellem Bønderne, at han er en Præstehader, hvilket han dog selv benægter.

Mogens Abraham Sommer var fodt i Ribe og blev i sit 24. Aar Lerer i Haderslev, efter at have provet adskilligt andet. Et Blik paa hans Billede i Dansk biogr. Haandleksikon giver allerede et Indtryk af Personen som noget ikke helt almindeligt. Han prædikede, siges der, en Art frikirkelig Kristendom i Tilknytning til Nordmanden Lammers .... udgav Pjecer og virkede som Kvaksalver. Han kom gentagne Gange i Konflikt baade med Myndighederne og Befolkningen .... og fik adskillige Fængselsstraffe. En ingenlunde ubegavet Mand, hvis Tro paa sin Mission ikke lader sig bestride.

Iblandt hans Smaaskrifter er: "Et evangelisk Foredrag, 
holdt i Arresthuset i Haderslev 4. Juni 1854 af M. A. Sommer'*. (2. Oplag, Aalborg). Her har vi Manden selv, som han gaar og staar, man kunde maaske rettere sige: som han haster og lwber i sit og sin Herres Arinde. "Verden holder i Dag Pinsedag" hedder det - "Da jeg var hos Eder i den tidlige Morgenstund og bøjede mine Knæ med Eder i Eders kolde klamme Celle, da talte jeg til enhver af Eder om Aandens Udgydelse .... Jeg har ofte erfaret det, naar jeg har været ene med Eder, at Eders Hjerte har slaaet haarde Slag, og Taarer har perlet i Eders Øjne, jeg vil aldrig glemme de Taarer vi med hinanden har fældet her i dette Fængsel, thi Herren har ofte besøgt os, og det er vort Ilaab, hans Naade har ikke været forgæves .... Jeg fylder i Dag mit 25. Aar, og da jeg i Morges bøjede mine Knæ med Eder, fortalte jeg Eder det jo, hvorledes Herren underligt har ført mig i disse 25 Aar. Jeg har jo skaffet Eder Bøger .... og I vide, at I kunne tale til mig som Ven til Ven. I Dag har jeg taget en Del af mine Venner hid'for at deltage i Opbyggelsen.....

Jeg føler mig nu træt, thi den ganske Dag har jeg talt her fra den tidlige Morgenstund, siden i Arbejdshuset, og endnu eeng:.ng skal jeg samle de hungrige Sjæle, som længes efter at høre om vor dyrebare Frelsers Naade, og derfor maa jeg slutte denne Gang. Imorgen skal jeg atter komme til Eder og da ville vi fryde os ved hans Livs Ord igen.

(Derefter en Bøn).

Han skriver med gammeldags Høflighed »Eder" stort, selv om det er Fanger og Tugthuskandidater, han taler til, men deres Navn staar ogsaa skrevet stort $i$ hans store Hjerte. At en ung Mand med denne Baggrund kunde samle nogle Hundrede af Haderslev- Borgere om sig - jeg tænker, det var mange af de Smaa - det undrer mig ikke.

Hans Tid i Haderslev blev kun kort. Præsten Fr. Helweg, der maaske var Lærerens nærmeste Foresatte, fik ham fjernet efter tre Aars Virksomhed. Lejlighedsvis har han dog holdt Møde i Byen senere.

To Taler, holdt i Had. 14. og 15. Juli 1859, lod han trykke samme Aar, og heri lases: "Der var en Tid, da jeg med megen 
Bekymring vendte mit Blik mod denne Stad. Jeg vidste, at ligesom Troldkarlene og de ægyptiske Koglere med deres Besvargelser kunde gøre de kraftige Gerninger efter, saaledes kunde de gjorte Kongepræster [et yndet Udtryk hos Forf.] med deres blinde Iver og store Tale gerne ogsaa forfore Guds udvalgte Folk' .... Disse gjorte Kongepræster har ingen Tro, derfor har de heller ingen Kraft, de leve med Verden og tragte efter alt, hvad Verden byder dem, Embeder og faste Lønninger og magelige Dage og derfor kan de ikke vidne om, at deres Tro er den Sejr, som overvinder Verden'.

Om sig selv siger han: "Jeg veed, jeg har modtaget et stort Naadepant, hvormed jeg skal aagre - maaske blandt 7000 fandtes ikke Een, som Herren havde udrustet med Aandens Kraft og Myndighed til at forkynde Ordet, som han har kastet det $\mathrm{i}$ min Lod, saa har jeg ogsaa at bringe en desto storre Rente!

Biskoppen, Provsten og Præsten har spillet den hellige Mand saa længe $\mathrm{i}$ «det hellige Embede«, skrev han allerede Aaret iforvejen, "at han virkelig tror, han er en hellig Mand i et helligt Embede - - veed ikke andet, end at han lider, forsager, bliver bespottet, foragtet og forfulgt, saa han græder for sin Kone og fortæller hende sin haarde Skæbne, raadfører sig med hende, orn det ikke er det bedste, at de flygte for dog at frelse Livet, indtil hun ved fornuftige Ord bringer Manden tilrette, overbeviser ham om, at det hele er kun en Drøm, en Følge af det tykke Blod, der er fremkommet ved, at han har gjort sin Bug til sin Gud». - Han tilraaber sine Læsere: "Skiller Eder fra dem, I mit Folk; thi deres Øjne blive opladt for, at Folkekirken er den Babel, som Johannes ser at falde". Og han slutter: "Saaledes være disse Ord udsendte i Vorherres Jesu Kristi Navn til Vejledning for de Enfoldige, der ønsker at frelses fra denne vanartige Slægt«.

I et Skrift, som under Navnet Dr. Johannes Theodorus saa Lyset i 1864, lod han trykke med store Bogstavèr: «I Slanger! I Øgleunger! hvorledes kan I undfly Helvedes Dom - I Aarhundreder have nu Præsterne bedraget Folket - - - der vilde ikke 
være een af Hundrede, der vilde føle noget Savn, naar Gejstligheden takker af. - Danmark kan takke Gud for Dr. Søren Aabye Kirkegaard, han er enestaande i vor Samtid, og ikke alene i vor men i de forgangne Slægter op til Apostlenes Dage har ingen talt som han."

Det var den Lasning, som i de Dage laa paa Menigmands Bord i Haderslev, og saa "Dannevirke». Hvad fik Menigmand vel ellers at læse? Da maa uden Tvivl de Kierkegaardske Toner vare gaaede ind i hver Mands Stue, hos de liprde Tænkere og aandelige Førere, ja, og saa hos mange, mange smaa Folk, som jkke har megen Tid, maaske heller ikke Forstand til at granske i Videnskabernes dybe Mullvarpeløb, men som ofte har et Hjerte, der umiddelbart forstaar visse Grundsandheder. Hvor meget der kom ud paa Gader og stræder af disse Bevagelser paa Aandslivets og Sjælelivets Omraade, ved vi ikke.

Hvor dybt Sindene var grebne, ses af et Brev, som en aandfuld Kvinde skrev til det lille Kirke-Lgeblad "Brevbærer mellem Kristne«. "Vi har i næsten to Aar«, fortæller hun, "haft en overvættes Naade, idet Herren har sendt os en Mand, der er saare sjælden begavet med Guds Aand og fyldt med hellig Ild - - - At han - og jeg tror ene han - kan og er istand til at virke paa Folket og fore det til Kristum, er en almindelig Mening her, fordi han er saa a lsidig, navnlig ikke for streng Dansk. ikke for streng grundtvigsk eller streng herren hutisk. Egentlig saa hælder han vel mest til $\mathrm{K}$ i e rkeg a a $\mathbf{d}$.... Han har holdt Bibellæsning og Forklaring hver Aftell over det gamle og ny Testamente; i lang Tid var det kun for Børn, men senere blev det saa besøgt af Eldre, at Skolen, der dog rummer omtrent 300 Personer, ingensinde er stor nok... Man kan vel sige, at han prodiker lige saa meget med sit Liv som med sit Ord, thi han er afholden og forsagende $i$ alle Ting og dog blandt Børn ganske selv et Barn. Da vistnok mangen haard Kamp er gaaet gennem hans Hjerte, har det efterladt dybe Spor i hans Træk; jo længere jeg ser paa ham, desto skarpere blive de mig “....

Mogens Sommer naatte altsaa rejse. Hans Liv, som altid 
havde været fullt af vidtigftighed, blev det end mere siden. Men lad ham fare.

Vi er komne for langt frem i Tiden. Endnu er Droftelsen i "Damnevirke" $i$ sin Begyndelse.

En Maske, U. K-d., dukker op og taler godt for sig. "Dannevirke" gør vistnok Ret i“ - siger han —, mu og da at henlede sine Laseres Opmærksonıhed paa Dr. s. Kierkegaards Virksomhed for at aabne Øjet for, hvad der er sand Kristendom, og hvad der er Skrøntkristendom. Bedre var det, om "Fæedrelandet" med hele Rakken af hans Torden-Artikler kom i alle Huse for at vidne, at det heller ikke staar ret til hos os Protestanter ... Dannark er ikke opgivet, det elskes [nenılig: af Gull; men det sover og drommer, derfor skal det opraahes - ".

En fortørnet Præst i Nabolavet kommer farende, river Masken af Personen, og raaber, at han hedder Illik Kjærgaard. Men vi er lige kloge og kender ham ikke. Masken taler to Gange og aldrig mere. Men nu er ogsaa Prasteskabet, Theologerne, Sandhedsvidnerne, komne i Bevagelse.

F. E. Bojsen i Vilstrup har sin egen "Budstikke», et Tidsskrift, i hvilket han aandrigt og veltalentle behandler Bibeltekster og vigtige Sporgsmaal efter grundtvigske Synspunkter. I Bladets mange og fyldige Aargange har Søren Kierkegaards Sag ikke forstyrret den hyggelige og menneskevenlige Tone; sjældent nævnes den, aldrig med nogen dybere Alvor. Men Udgiveren giver en enkelt Gang Mode i "Dannevirke«s Spalter iblandt de andre stridende og erklærer, at det dog vel ikke kan kræves af Præsterne, at de skal opgive deres Embeder. "Vi skal vare villige til at bringe Opofrelser, naar disse virkelig kraves af os, men vi vil ikke bringe dem for at være dem til Behag, der ikke kan unde os vore Indtægter, hvad enten vi gør Gavn for dem eller ej. At ville være Martyrer, hvor det ikke kræves, anser jeg for lige saa daarligt, som ikke at ville være det, naar det kræves".

Saa tier den erfarne Mand i Vilstrup. Han glemmes hurtigt, thi nu kommer Ungdommen. Som en Raket fuser det op i Luften, knitrende, lysende. Det er unge Hr. Peter Christian 
Zahle, Præstesøn fra Nørrejylland, Kandidat i Theologien, Nationalakonom, Bondeven, Rigsdagsmand, alt i alt et Uro paa den danske Skueplads. Dengang han tog Ordet i "Dannevirke", vidste vel ingen, hvor han kom fra, men senere har Historien godt kendt hans Navn. Han var Broder til Nathalie $Z$. og Onkel til den forhenv. Statsminister.

De første Stykker af "Øjeblikket“ var udkomne. Striden og Ophidselsen ud over Landet steg fra Dag til 'Dag. Bladet "Dannevirke" er med. Der trykkes næsten ikke et Nummer, uden at der hares en Genlyd deri af de store Kampe. P. Chr. Zahle's første Emne hedder: Præsten og Prædikestolen. Redaktøren gør sine Bemærkninger dertil, bl. a. denne: "I Henhold til Indholdet af hans Artikel da er jeg i meget ikke enig med ham, men fordrer langt grundigere Reformer, navnlig Prædikenens Ophør i Kirken og Ordets Forkyndelse fremkaldt ude i selve Samfundet."

Dette Nummer af Dv. syntes Politimesteren ikke om. Saa vidt maatte man ikke gaa, dersom der skulde være Lov og Ret i Landet. Bladet blev beslaglagt.

Men den unge Kandidat og Rigsdagsmand skrev videre. Der var Ild $\mathrm{i}$ hans Pen. Om "Den hellige Kæde" skrev han - om "kristelig Rangfølge" - om »Bisp, Præst, Degn«, hvilken sidste Artikel sammen med nogle Udpluk af "Øjeblikket« atter hlev Aarsag til, at Bladet blev beslaglagt.

En Dag segnede S. Kierkegaard om paa Gaden, dødssyg. Han maatte holde inde med "Klemtningen". Hans Gerning var gjort. Men i Haderslev og ud over Landet gik Klemtningen videre. P. C. Zahle skrev om »Præst og Præst. Offer og Offer. Arv og Arv«. Her spørges, hvorfor man i Reformationens Dage ikke fejede Præsteskabet ud med saa meget andet. Der svares: "Læs derom Luthers Hyrdebrev, som Kaptajn Thurah (Læreren v. Tønder Seminarium?) nylig har oversat. Staten og Fyrsterne sagde som før St. Peders Stol: Nej Stop! Præsterne kunne vi godt bruge. De kan holde os Folket i Ave. Dem kan vi dreje og vende, som vi har Lyst, mod at give dem fede Embeder". Om Arven siger han, at nu arves et evigt Liv ved Fødselen, alt- 
sammen i Modstrid med det Ny Test. "I Sandhed, Kulturen stiger". Højtideligt føjer Redaktøren til: Det Emne, som Hr. Kand. Zahle ovenfor har behandlet, sysselsætter i vor Tid meget de troende Lægfolk. For at paaskynde Spørgsmaalets Afgørelse opfordrer jeg herved dem, som ansee Titelen Præst og Præsteembedet overhovedet en særskilt Præstestand, for kristelig hjemlet, til i Dv. at modbevise Hr. Zahle.

P. C. Koc h.

En Præst i Haderslev følte Spørgsmaalets og Opfordringens indre Berettigelse og sendte et Svar. Det var Johannes Fibiger, Lærer ved Latinskolen og tillige Hospitalspræst. Hvorfor han blev den eneste, der gjorde sig den Umage, enten for sin egen eller for Menighedens Skyld, fristes man til at gøre sig sine Tanker om. Sikkert var langt ud over de levende Kristnes Kreds Sindene i stærk Bevægelse. Lærerne ved Skolen, der hver Dag stod imellem tænkende og spørgende Elever, Præsterne, der hver Søndag stod overfor en Tilhørerskare, iblandt hvilken de fleste havde læst alle de drøje Anklager mod Præst og Kirke; opvakte Mennesker i Mogens Sommers Forsamlinger, som kendte deres Bibel; Provster, Bisper og andre Kirkens Tilsynsmænd - var der ingen af dem, som vilde stille sig ind i den aandelige Kamp og tage et Stykke Ansvar paa sig? De tav vel ikke, sikkert ikke. Men Peter Kristian Koch fik ikke Svar af dem. Det er i det hele taget forbavsende, $\mathbf{i}$ hvor ringe Grad den kristne Menighed eller Kirkefolket dengang saa vel som senere her i Slesvig har taget sig af sin Kirke og dens aandelige Ejendom.

Dengang altsaa var Præsten Joh. Fibiger ene or at give et sagligt og historisk Forsvar for Præstestanden. "Vor Tids Skade", hæudẹr han, "bestaar ikke $i$, at vi have lovligt beskikkede Præster, men i, at vi have saa mange daarlige Præster. Embedet er helligt, men selv har Præsten hverken ved Fødsel eller af hellig Karakter noget forud for de andre Troende. Jeg har heller aldrig sporet, at nogen Præst hos os i mindste Maade har gjort Fordring derpaa». 
Et Mellemspil foranledigedes atter af Ungdommen. I sit Mindeskrift om Sognepræst Chr. H. de Thurah fortæller F. Hjort: "I den saakaldte Sandhedsvidnestrid deltog Thurah meget kraftigt og efter manges Mening paa en særdeles heldig Maade i sit Riimbrev til Johannes Forføreren, alias Dr. Søren Kierkegaard", der blev efterfulgt af "Hvorfor netop saaledes, Præmisser i Sagen C. H. Thurah kontra Dr. Søren Kirkegaard" og Mester Jakel, en Dyrehavsscene gengivet efter Virkeligheden" (Tre Gange efter hinanden staar Navnet $K$. med fejl Bogstavering).

"Dannevirke" kaldte Rimbrevet et Skamskrift. Men det fik et Gensvar i et af Bladets Numre, som baade for Formens og Indholdets Skyld her delvist skal meddeles:

Mit Indtryk af stud. Thurah's Rimbrev.

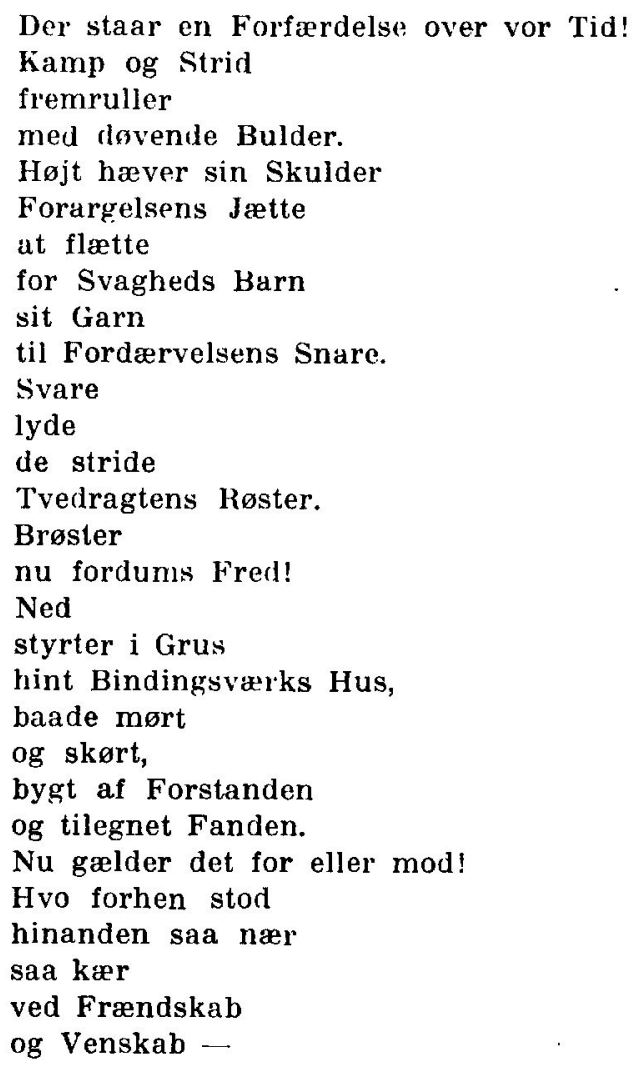


"Jeg vide det maa, du svare mig paa:

Hvorlunde bor Herren i sinde?"

Da hedier det Ven eller Fjende.

I dit dunkle skod

hvad dølger du, Tid?

Hvorhen stunder din Id?

Hvad skal mode vort $\varnothing_{j e}$

hist paa den høje

straalende Bue,

naar atter vi skue

Morgengryet?

Twender du Nyet

brat for en bedre Aand?

Løser de Baand

som en Tid saa lang

Guds Menighed tvang?

Hvalver du

nu

som hin Stund

i lysende Forgrund

Brynet

Forklarelsessynet

klarlig at skimte?

skulle saa glimte

Troslivets Lyn,

et Opbyggelsens Syn,

som Kornmod at styrke

i Jorderiges Mørke

Guds Riges Sad?

o. s. v.

(undertegnet:) - $\mathbf{d}-\mathbf{n}$.

I Slutningspartiet, som ikke meddeles her, faar Studenten sin Dom; men om S. K. hedder det smst.:

- ham

Aandskæmpen, med Tankens skarpeste Syn, med de glimtende, sælsomt fængende Lyn, muligt vor Fjende, muligt, naar Kampen stunder til Ende:

vor Ven -

Jeg er sikker paa, at med disse Ord er mange ærlige forstaaende Menneskers Tanker om S. K. i de Dage ret nøje gengivne: 
Muligt vor Fjende - muligt vor Ven.

Saa gik Striden videre. Og inden P. C. Koch tænkte sig om, havde han kørt sit Blad ud paa Afgrundens Rand. Paa Grund af Udtalelser om forskellige kirkelige Anordninger saa vel som i Forbindelse med de Kierkegaard'ske Øjeblikke blev der paafort hain en Proces af Ministeriet. Advarsler var gaaede forud, men havde ikke frugtet. Anklagen gik ud paa, at Landskirken (i Hertugdommerne) var blevet angrebet saa stæerkt, som den overhovedet kunde blive. "Jeg i det mindste«, siger Anklageren, "indser ikke, hvad Værre og mere Fornærmeligt, der skulde kunne siges om den; men foruden dette er de brugte Udtryk i højeste Grad utilbørlige og fornærmelige for Regeringen og for dell hele gejstlige Stand« o. s. v. Der andrages paa $1 / 2$ Aars Fængsel, eller en følelig Mulkt og Betaling af Omkostningerne.

$\mathrm{Nu}$ var det passende, om P. C. Zahle skrev en Artikel om at lide for Retfardighed, og den skrev han, uden at han dog kom til at lide med.

Dagen efter kom i»Dv.« Meddelelsen om Søren Kierkegaards Død.

"Ja, nu er det forbi", stod der at læse nogle Dage senere, "den mærkelige Mand med den »vidtløftige Litteratur" og den "private Religion" er død. Kun en Handling staar tilbage: med de tre Spader Jord at indvi den Afdøde som Alt, hvad der er kommet af Jord, til Jord igen - og saa er det forbi...

Mell trindt omkring i det Folk, han tilhørte, hvis Sag han tjente, hvis Sprog han med sønlig Hengivenhed og med næsten kvindelig Forelskelse var stolt af at have den Ere at skrive, trindt omkring i dette Folk er der Sorg hos de Enkelte, hvem han sogte og fandt, efter hvem han ligesom udstrakte sine Arme - disse Enkelte, der saa forunderligt føler sig tiltrukne af, hvad han skrev .... de se med Kærlighedens hele Beundring tilbage paa det Liv, som - hvad der er saa sjældent $i$ "Kristenhed" - helt igennem sigtede efter Idealet.

Skulde den, der nedskriver disse Linjer, sætte en Indskrift 
paa den Hensovedes Grav, da blev det denne: Det er paa den høje Tid, at vi faar vide, hvad det vil sige at være Kristen.«

$$
\text { (undertegnet:) s.-h. }
$$

En Maaned senere sagde Peter Christian Koch Farvel til sine Læsere. Han havde solgt Bladet og rejste til København.

Om denne sidste Begivenhed skal jeg kun kortelig gengive, hvad P. Lauridsen har udtalt i Hist. Tidsskrift A. R. 2. B. (om sønderjydske Førere). P. C. Koch var imod Forventning efter Treaarskrigen kommet $i$ et spændt Forhold̀ til det danske Styre, De slesvigske Ministerier havde standset hans nationale Vækkelsesarbejde, og han lagde da dette Arbejde om i religiøs og kirkelig Retning. Fra Nytaar 1855 blev Dv. halvvejs et religiøst Blad. Saa kom Kierkegaardsrøret. P. Lauridsen anfører følgende Brudstykke af et Brev, som Præsten Fr. Helweg skrev i dette Tidsrum: "Hvad det kierkegaard'ske Spektakel angaar, saa skal min gode Raaslaff (som truede med at fratage Dv. Koncessionen) vogte sig for Yttringer, som: Jeg vil ikke have det udbredt i Slesvig .... Koch kan deri intet concedere, han gør det heller ikke, og uagtet jeg ingenlunde er en Kierkegaardianer som han, finder jeg heller ikke, han bor".

P. C. Koch skrev selv til Flor: "Forbudt blev det mig da strengt at optage noget af Dr. S. Kierkegaards Polemik eller at omtale denne, fordi Raasløff og Regenburg ikke vilde have dette Emne ind i det slesvigske«.

Under disse truende Trængsler tabte P. C. Koch og hans Hustru Modet og opgav Evret. Bladet "Dannevirke«s Deltagelse i S. Kierkegaards Kamp var dermed tilende.

Men vi har under denne Kamp nogle Gange mødt et Navn, som her maa fremdrages endnu engang. Det er Johannes Fibiger. Hans Erindringer er delvist blevne trykte under Titlen: "Mit Liv og Levned, som jeg selv har forstaaet det". Her faar man ogsaa et Indblik $i$ hans Stilling til S. K. Ved sin Afrejse fra København havde han lagt paa sin Forlovedes Bord et Bind af S. K. og en Roman, selv førte han samme Slags Læsning med sig. "S. Kierkegaards Skrifter af opbyggelig Retning vokser i 
de Aar, og vi var begge lige opfyldte af den. Amalie stjal Herregaardens Toilettetimer for at fordybe sig i et Bind Taler, og jeg laa i de søvnløse Nætter i min Feber og læste Kærlighedens Gerninger". Iblandt hans digteriske Arbejder er et Skuespil "Johannes Døberen" og et "Profeten Jeremias", der tydeligt nok røber, af hvad Aand Forfatteren er. I "Dannevirke« kom han til at ledsage og belyse den standende Strid med en Række Artikler, som han kaldte Løverdags Læsning og som skulde være en Forberedelse til Søndagen. Hele Vejen har han S. K. i Tanker, og tilsidst tilstaar han aabent: "Nu hviler han i sin Grav, og hans Sjal er der, hvor hvert Ord, baade de tilbørlige og utilbørlige vejes paa en anden Vægtskaal end den, vi i vor Kortsynethed og med alle vore jordiske Hensyn plejer at bruge. Alle de haarde Knuder, han knyttede for os, skal ikke forvirre den Herre Kristus, men jeg ved ikke, hvorledes de bliver løste. I hvad jeg har skrevet, har jeg dog søgt at løse dem efter den Oplysning, der er mig forundt. Jeg har vel kun en enkelt Gang nævnt hans Navn, thi jeg vilde, at stille Folk, der ikke ser sig vidt on i Verden, heller ikke behøve det, skulde kunne læse mine Ord ogsaa uden Hensyn til den Strid der foranledigede mig til at tage Ordet - - Derfor ved jeg min Samvittighed fri, naar Kirkens Lærere er blevne beskyldte for ved denne Lejlighed af Menneskefrygt at have holdt sig tilbage i Tavshed ".

Han og andre Præster maatte tage imod adskillige Ytringer, mundtlige saa vel som skriftlige. En af dem sluttede med disse Ord: "Luk De Deres Kirkedør og skriv uden paa: Her vrøvles ikke mere af J. Fibiger, Sjælemyrder".

Saaledes gik Aaret 1855. Peter Kristian Koch er forsvundet og der bliver stille $\mathbf{i}$ "Dannevirke«s Spalter, Søren Kierkegaard ligger $i$ sin Grav, Mogens Sommer er her endnu, men staar for Fald. Men Provsten H. P. Kofoed-Hansen - hvor er han blevet af?

$\mathrm{Nu}$, han sidder lunt inden Døre og skriver paa en Bog, som hedder "Tegnet fra Himmelen«, en kristelig-psykologisk Afhandling (trykt 1856). Derefter giver han sig i Lag med en Bog: "Dr. S. Kierkegaard mod Dr. H. Martensen" (ligeledes trykt. 
1856). Han følger altsaa med. Til den fænomenale Verden forholdt han sig som den, der bare er paa Gennemrejse (J. Fibiger), men han var dog mere end Tilskuer. I Aaret 1857 udkom: "Dr. S. Kierkegaard mod det Bestaaende", i 1859: "Nyt Gammelt. Breve over Tertullian fra ux til xu«, 1860: en Samling Salmer og Sange, 1863: "Indledninger, givne fra Prædikestolen« (en Prædikensamling) og endeligt i 1864: "En Røst i Ørkenen fra Prædikestolen ", det sidste Arbejde fra hans Haand, som fuldførtes og udkom i Haderslev.

Blev der ved S. Kierkegaards Død stille i Haderslev, i hvert Fald tilsyneladende og paa Overfladen, saa lagde Tankernes Strid og Tummel sig ikke hos Provsten, skønt han ved Juletid var flyttet ud til Præstegaarden i Gammelhaderslev og fra sin store Have ved Dammen kunde forfriske sin Sjæl ved Landskabets hele Ynde.

For ham vilde Tanke og Ord og de trykte Bøger, som han havde mange af, ikke slaa til. Det gjaldt om at eksistere som en Kristen. Hans Samvittighed kom i stadigt større Pine. Naar han forestillede sig det Ny Testamentes Kristendom, Apostlenes Færd og Evangeliets første Forkyndere i den Belysning, S. K. havde fremkaldt, saa blev der først Uro, derefter Selvbebrejdelse og tilsidst en Beslutning: Han kunde og burde ikke være Præst. Han kunde ikke fyldestgøre de Krav, som man paa Idealets Vegne - og paa Redelighedens Vegne - maatte stille til en sand Kirkens Tjener.

Hen paa Aaret 1857 indgav Provsten sin Afskedsbegæring. I et Brev til Chefen for Kirkeafdelingen $i$ det slesvigske Ministerium J. Regenburg udtaler han: "Naar jeg ansøger om min Entledigelse, saa er det sket ifølge min Samvittigheds Bydende. Jeg har kæmpet længe, maaske for længe derimod og kan ikke Andet." Da man nødigt vilde slippe den dygtige og begavede Mand, erklærede han sig villig til at nøjes med en Permission, og Ministeren indberettede paa følgende smukke Maade til Kongen: "Fra Sognepræsten for Gammelhaderslev Menighed og Provsten for Haderslev Provsti, H. P. Kofoed-Hansen, har Ministeriet modtaget et Andragende, hvori han, hos hvem de senerc 
Aars kirkelige Bevægelser have fremkaldt en Kamp, der har gjort ham det $i$ høj Grad vanskeligt at varetage sit Kald, har yttret det Ønske, at der maa tilstaas ham en Permission, hvortil han føler sig trængende sjæleligt endnu mere end legemligt og hvorved han haaber at kunne sættes istand til at genvinde den Fred og aandelige Fasthed, der er nødvendig for at udøve sit Kald i Fortrostning til Herrens Velsignelse .... Ministeriet kan for sit Vedkommende kun ønske, at denne dygtige, redelige og samvittighedsfulde Embedsmands Begæring maa blive opfyldt -

Efter at have tilbragt en Tid i Stilhed og derefter foretaget en Udenlandsrejse, vendte Provsten tilbage til sin gamle Gerning i Højsommeren 1858. D. 4. Aug. indviede han den nybyggede Kirke i Sommersted. Da Hertugdømmerne frareves Danmark, opgav H. P. Kofoed-Hansen sin Stilling i Haderslev og blev et Par Aar senere Præst paa Lolland og Stiftsprovst for LollandFalster Stift. Han skrev endnu: "Et Folk - Folket" (1869) "Her og Hisset. Breve til en Afdød fra M. Oriente. Udgivet af Kofoed-Hansen." (1872) - "Livslænker. En Fortælling af Jean Pierre" (1875). Sine sidste Aar tilbragte han i Københavin, hvor han traadte over til den romersk-katolske Kirke.

Om hans Liv og Tænken saa vel som hans Forfatterskab har P. P. Jørgensen skrevet en Bog paa over 600 Sider med Titel: $H$. P. Kofoed-Hansen (Jean Pierre) med særligt Henblik til Søren Kierkegaard. Særlig til Belysning af aandskulturelle Strømninger $i$ det 19. Aarhundredes Danmark. Bogen, der er en Afhandling for den filos. Doktorgrad, er forsynet med en meget smuk Tegning af Elsabeth Jerichau.

Som det ses, udkom hans Skrifter i Kierkegaardsstriden først efter S. Kierkegaards Død. H. P. Kofoed-Hansen har selv beklaget dette og ment, at dersom han havde naaet at faa sagt, hvad han vilde sige, et Par Aar før, da vilde S. Kierkegaards sidste voldsomme Angreb have formet sig anderledes. P. P. Jørgensen indrømmer, at dette Haab maatte have nogen Berettigelse: "Den Formodning, at han, hvis han havde været to Aar tidligere paa Veje, vilde have formaaet i Egenskab af redelig gejstlig at be- 
virke om ikke en Metamorphose, saa dog en Modifikation af Kierkegaards sidste Fremfærd, tør næppe forvises fra det Sandsynliges Enemærker« (a. St. s. 518).

Hermed forlader ogsaa vi Haderslev. Ved Afskeden falder vort Øje paa det nyeste Nummer af "Budstikken", hvor en Indsender erklærer: "De Søren Kierkegaardske Consequentsmageriers heftigste Eftervirkninger have nu saa temmelig lagt sig, og kun nogle Surmulerier lyder endnu hist og her over, at denne Skribents Tarvelighedsanvisninger ingen Frugt have baaret, men at man f. Eks. endnu ser En indbyde sine Venner. til et Middagsmaaltid, en anden at lægge et Gulvtæppe, som gode Venner have foræeret ham, paa sit Gulv o. d. l."

Uvejret er altsaa drevet over, og vi kan tage en Tur paa Landet.

Ud til en Præstegaard i Vest. Til en Digter.

Da Mogens Sommer udgav et Par af sine Taler, opstod der inde i Bogen en tom, ubeskrevet Plads, som den ivrige Lægprædikant rimeligvis daarligt kunde forsone sig med, hvorfor han paa dette Sted lod trykke følgende:

Efterskrift. Kjære Læser! Vil du læse noget godt og Nyttigt, saa anskaf dig en Bog, som hedder: Breve fra Helvede, udgivet af $M$. Rowel.

Du vil i al Evigheds Evighed ikke fortryde det.

M. Rowel - det er Digteren. Han hedder med sit rette Navı Valdemar Adolf Thisted og ser kønt og tiltalende ud. Han bor heller ikke i Helvede men 'i den gamle lavloftede Højrup Præstegaard, som nu er forsvundet. Resterne af et gammelt Træ staar endnu i Haven, og man siger, at det stod uden for Studerestuens Vindue. Her har vel saa Digteren siddet og skrevet Kapitel efter Kapitel, mens Bogfinken sang sit Stykke i Træets Krone. Bogfinken er fløjet og Digteren er glemt.

Brevene fra Helvede var allerede skrevne i 1846. Andet Oplag udkom 1867 samtidigt i København og London. De siges at have vakt stærkt Røre, ogsaa i Tyskland. Først 1855 kom Forfatteren til Højrup som Sognepræst, da var Kierkegaardstriden i fuld Gang. En hel Række Fortællinger og Rejseskildringer 
havde set Dagens Lys under Navnet Emanuel St. Hermidad. Ogsaa "Dannevirke" havde lagt Mærke til dette Navn. Flere af disse Værker oversattes paa Tysk.

I Højrup hengik nogle Aar, uden at Verden mærkede noget til den ellers saa travle Forfatter. Støjen i Haderslev fristede ham aabenbart ikke til at lade høre fra sig, skønt det Navn, som Alt drejede sig om, forlængst havde faaet sin Betydning for ham ogsaa. Den Bog, han udgav 1859, hed: "Præstekald. En Samling af Breve, udg. af Herodion 2 Dele.« Dens Indhold og Mening er aabenbart et Forsøg paa at lægge et Menneskeliv tilrette efter de Anvisninger, Forf. havde fundet hos S. K., hovedsageligen med Selvfornægtelsen som det store Afgørende. Forsagelsen drives efter det givne Mønster saa vidt, at den unge Mand i Fortællingen giver Afkald paa den Elskede. Men medens S. K. ikke fandt tilbage til Regine Olsen og holdt "Gentagelsen « $\mathrm{i}$ den Forstand for umulig, saa lader Herodion helt i Slutningen af sin Bog forstaa, at nu har de to elskende Mennesker lært Selvfornægtelsen at kende til Bunds, og nu maa de til Belønning - blive Mand og Hustru.

Et Par københavnske Blade gav sig til at rakke ned paa Forf., og han saa sig nødsaget til at forsvare sig. Først skrev han et lille Skrift: "Præstekald, anslaaet og ansat af "Fædrelandet« og "Dagbladet«. Nogle Træk til Belysning af Kritikens Standpunkt her i Danmark, ved Herodion«. Senere fulgte: "Til Christi Menighed fra Præsten i Hvilsted“. Endnu udgav han i Højrup - for at tage det med det samme - nogle Søndagsprædikener og nogle Digte.

"Præstekald" - siger han i Forsvarsskriftet - er Titelen paa et Værk, som i den senere Tid, skjøndt optagen og overfyldt (neml. Tiden) endog over det Sædvanlige, har vakt en ikke ringe Opmærksomhed, saa vel i som uden for det religiøse Livs Kredse. . Han (Forf.) skriver om det, som er Mennesket helligt, om Gud og hans Rige og det evige Liv. Han giver det til Bedste, som plejer at være Mennesket dyrebart, sin egen Ungdoms Minder, og man stempler ham uden videre som en Hykler og Bedrager, der ikke mener eller føler et Ord af, hvad han siger.» 
En Hykler var Herodion nu sikkert ikke. Han foretager i "Præstekald $\varkappa_{i}$ et Opgør med sig selv. «Er jeg en Præst« - spørger han sig selv -, som i min korte Embedstid allerede har sporet hin aandelige Ladhed, som Kjødet begunstiger og Djævelen opelsker, den lune Følelse af at have sit paa det Tørre? .... Er jeg en Præst, som finder stort Behag $i$ at omgaas mig selv alene .... som taler højt om at være Alt for Alle, men i Stilhed bereder mig til at vorde Alt for mig selv?"

"Nu veed jeg" - skriver han til den Elskede -, hvad Kjærlighed er. Kun Eet manglede til en fuldkommen Kjærlighed imellem os - at den skulde lære at fornægte sig selv. Hvad er Kjærlighed uden Selvfornargtelse?«

Indervejs moder vi da, som forventet, S. Kierkegaard.

"De spørger mig, i hvilket Forhold jeg staar til S. K. Deres Spurgsmaal har overrasket mig, dels er det længe siden, jeg har tænkt paa S. K. Men desuagtet maa jeg vedgaa, at jeg unægtelig ifølge hele min senere Tankeretning staar i et vist nøje Forhold til ham .... Visselig han mente noget med, hvad han talte tilsidst, da han følte, at han kun havde faa Ord tilbage at sige i denne Verden! Hans Liv var et saare langt Ord, men Akcenten ligger paa den sidste Stavelse. I et Skrig gik han bort, og dette Skrig genlød længe efter ham, genlyder endnu. Ogsaa Gud har hørt dette hans Skrig; det er naaet til Himlen førend han selv.... Vi passede ikke for hinanden og adskiltes snart for aldrig mere at nıødes.... Mit første Værk udkom ikke lange efter hans Enten - Eller. I deres himmelvide Forskellighed vakte begge Værker Opmærksomhed. Jeg læste hans Bog, han laste vistnok aldrig min. Jeg var ham for ubetydelig; han forblev mig uforstaaelig. Først i sine sidste Ord tiltalte han mig virkelig i enkelte høje klare Toner, som sejrende løde gemnem vilde Dissonantsers Chor.... Han forekom mig $\mathbf{i}$ disse sidste $Ø$ jeblikke at svieve paa Grænsen imellem Vanvid og guddommelig Inspiration; jeg hørte ham som en Døende, for hvem de almindelige Begreber begyndte at forvirres, men hos hvem de herskende Ideer træder frem med en forunderlig Klarhed og Styrke. I næste, ja i næste Øjeblik maatte det 
briste... Straks efter at jeg havde læst Deres Brev, gik jeg hen og opsøgte blandt mine Bøger et lidet Bind, hvor jeg i sin Tid havde ladet Kierkegaards "Øjeblikke" og nogle didhen hørende Pjecer indhæfte. Jeg havde lige saa lidt tænkt paa Kierkegaard som paa hans Bog, siden jeg var kommen her til Hvilsted. Et Øjeblik stod jeg med Bogen i Haand; saa satte jeg den atter roligt hen paa dens Plads. Det var bedre, at jeg for Tiden ikke læste deri«. _ - -

Digtere er et eget Slags Folk. Sommetider har de ikke helt Rede paa sig selv. Vi siger høfligt Farvel til Højrup Præstegaard og Præsten i Hvilsted og fortsætter Rejsen ad Ribe til.

Overhyrde i Ribe Stift er Biskop Jakob Daugaard, en Mand af "naturlig Jævnhed forenet med stor aandelig Overlegenhed, derhos afholdt af alle, med hvem han kom i Beroring ". Hans biskoppelige Myndighed naaede i Syd til Tønder, Før og Amrum. Men hans vaagne Hyrdeøje naaede længere. Alt, hvad der tonede frem i Tidens Bølgegang fra Nord og Syd kom ind under Bispens Blik og Dom. I Hyrdebreve og Rundskrivelser talte han med sine Præster derom.

Datteren Kristine Daugaard har nedskrevet en umaadelig Masse om sin Fader og sit Hjem. To Bind er trykte, to andre paa over 1000 skrevne Sider, ligger i Kongeligt Bibliotek. At gennemblade disse Erindringer, der er skrevne med Forstand, er det samme som at leve en Stund i Ribe Bispegaard, være med i deres Glæder og Sorger, læse deres Breve, kende deres Tanker og ledsage Faderen paa hans Visitatsrejser og Sonnerne paa deres Rejse til Københavns Universitet.

Det var i Aaret 1850, at S. Kierkegaards Bog: "Indøvelse i Kristendom« udkom. Forf. har selv kaldt den et sidste Forsvar for det Bestaaende. Paa det Tidspunkt var Biskoppens to Drenge som Studenter i København. Petrus, den yngste, tilstaar at han ikke kender noget videre til denne Forfatter. Hans derimod, den ældste, læste S. K. i Begejstring for hans Forfatterskab og med Kærlighedens Forstaaelse og inderlige Tilegnelse - som Søsteren fortæller. Han kunde ikke lade være med at meddele af sin Begejstring i Breve til Hjemmet og ved Lejlighed 
endog at sende dem en af S. Kierkegaards Bager. Men Faderen lader ham vide: "Du, Hans, skal ikke anbefale mig flere af Mag. Kierkegaards Bøger, thi den Indøvelse or mig en stor Pine og Plage."

Dette smertede nu Hans. Men senere skrev den gode Bispinde, som ellers var godt nok enig med sin Mand: "Du maa ikke tro, min elskede Hans, at vi ganske forkaster S. K. Jeg hører, og Fader læser med Fornøjelse og Opbyggelse hans Kærlighedens Gerninger. Men den meget omtalte Bog opbygger mig næsten aldrig - hvad vindes der ved det Ordbram? a Imidlertid har Bispinden nok alligevel ikke faaet rigtig fat paa alt, hvad der læstes, thi et Par Aar efter skriver hun til Hans: "Det vil vist interessere Dig, at jeg nu for Alvor har givet mig til at læse Kærligheds Gerninger. For en 14 'Dage siden var her nogle Herrer: Stiftsprovsten, Koch, Schousboe og d'Origny og der blev talt meget om en Dame, der med saa megen Kundskab havde udbredt sig om denne Bog, og jeg kom da til at ytre min Undseelse og Misundelse.“ -

Din kjærlige Moder Thrine Daugaard.»

Saa maatte altsaa Thrine Daugaard for Alvor til at studere $S$. K. Hun vidste, hvad hun skyldte sin Stilling.

Hans var svagelig, fik Blodstyrtning og døde efter et Par Aars Forløb. Petrus besøgte i 1855 jævnligt sin syge Tante paa Hospitalet, hvor S. K. laa og ventede paa Doden. Da det oven omtalte Rimbrev af Student Thurah fremkom, meldte Petrus hjem: Chr. Thurah har i disse Dage udsendt et Sendebrev mod ham, som jeg saa henne hos Scharling, og som - jeg læste kun det allerførste - i det Mindste i Plathed ikke staar tilbage for Kierkegaards egne Produktioner - hvortil Faderen svarer: "Det er en Bog (neml. Thurahs), soin jeg ikke onskede, Du skulde have skrevet, og over hvilken uden Tvivl hans Fader vil blive meget vred; men den er ikke uretfærdig, den giver $K$. af hans egen Mønt, Snavs og Skarn, men ikke attisk Salt.

Saadan var Luften i Ribe Bispegaard. Valdemar Thisted kan med sine Bøger tra dette Tidsrum ikke have fundet megen 
Forstaaelse hos sin Biskop. Derimod blev han straks ved sit første Besøg i Ribe inltaget i Hans, begribeligt nok. Og da den unge Mand døle, skrev Digteren i Højrup et Sørgedigt, som man leste med Glæde i Bispegaarden.

Hvad Biskoppen i Ribe paa sine Rejser og i sine private Skrivelser talte med sine Præster i Stiftet om, kan jeg ikke sige. Brevene til Hjemmet er underligt tavse i den Henseende. Meu i sine Hyrdebreve har han jævnligt udtalt sine Meninger om S. Kierkegaard, Præsten Lammers i Norge, Mogens Sommer og Læreren i Mjolden, hvilken sidste vi snart kommer til at omtale.

Starkest har han dog udtalt sig, og skrappest lyder hans Ord i den Omgangsskrivelse, som han sendte ud i Stiftet den 12. Dec. 1855, efter S. Kierkegaards Død. Skrivelsen kan læses i Datterens Mindebog, men nogle Stykker af den maa fremarages her.

"Mine elskelige Brødre!

Det er en højst forunderlig og i mange Henseender sørgelig Tale, cler er ført offentlig til os og om os gejstlige, især i det sidste Aars Tid af ell mærkelig Mand, en dyb Tænker, som nu er hensovet, en Tanker, som, medens han maatte antages alvorligen at hylde Kristendommen og at bøje sig for den aabenbare Sandhed, dog og tillige synes at have villet paa egen Haand og ved egen Kraft hæve sig til de Højder, og trænge ned i de Dybder, hvilke den menneskelige Tænkning ikke kan naa eller gennemtrænge og ej heller ustraffet tør tilstræbe .... Især har han vendt sine skarpe, vi kunde næsten sige, giftige Vaaben mod Lærestanden (d. e. Præstestanden) i Kirken og benævnet alle dens Lemmer uden Undtagelse Slyngler, Løgnere og med flere slige Navne, som det ikke er værd at gentage, og offentlige Blade have ikke undset sig ved at tage hans og nu hans Efterfølgeres ligesaa plumpe som bitre Angreb op i deres Spalter og at hjælpe til, at hans Raab kunde høres saa vidt muligt $i$ den vide Verden. Vi kunde ikke uden Smerte, men vel heller ikke uden Harme lase, hvad der saaledes flød fra den Mands Pen, der havde og det visselig med stor Dygtighed og Nidkærhed beredt sig til den samme Tjeneste, som vi virke $i, \ldots$. 
Man har under dette Angreb vistnok ofte hort dem, som staae eller som mene at staae udenfor, spørge med ynksomt og foragteligt Skuldertræk: Hvad mon dog Gejstligheden vil sige hertil? Mon den kan tie til saadan Haan og Forsmædelse, som kastes paa den, uden at dømme sig selv skyldig, uden at kende sig selv værdig til den Foragt, som er den vist ....

Jeg mener, at naar vi bagtales, som sket er, da griber enhver af os allerførst $i$ sin egen Barm og spørger sig, om han føler sig truffen, forsker efter, om han ved en egennyttig og hovmodig Omgæengelse mod sine Nærmeste især mod sin Menighed, eller desl. har forarget nogen af de Svage ... V Vi kunne jo nemlig ej dølge for os selv, at der ogsaa findes dem i den gejstlige Stand, der forarge i Ord og Gerning, dem mod livilke Retfærdigheden har maattet udstrække sin Arm for at fjærne dem fra det Embede, som de have beskjæmmet i Stedet for at pryde det med et eksemplarisk Levned...

Nu er dog dette Navn (Sandhedsvidne - et Vidne om Sandheden) gjort os stridigt, nu er det sagt om os alle - uden Undtagelse - at naar vi prædike, 'da hykle vi. Jeg vil haabe, at dog de fleste af os kunne med Haand paa Hjerte svare herpaa: Saa vist som jeg er en Synder for Gud, saa vist gaae dog disse haarde Haansord forbi mit Øre uden at rore mit Sind og min Samvittighed; thi en Logner og Hykler er jeg ikke ...

At denne til en Tid saa sindige og sunde Tænkers Tale paa det sidste blev vild, at han "fægtede som den, der slaar hen $i$ Vejret", kan jeg for mit Vedkommende ikke forklare mig anderledes end ved at sætte denne hans Optræden i Forbindelse med den legemlige Sygdom, der greb ham midt i Stridens Hede og gjorde Ende paa hans Dage, og deri finde et Tegn paa, at den ellers saa lyse Aand til sidst har lidt af en partiel Formørkelse, og at han ikke ganske har været sui compos (ved sig selv).

$\mathrm{Nu}$ staar han for sin Dommer, som bedre end vi veed at afgare, hvor vidt hans Ret eller Uret har strakt sig, vi ville ikke dømme hain og langtfra ikke med fuld Bevidsthed tilmaale ham med det Maal, hvormed han, muligen uden klar Bevidsthed, har tilmaalt os.« 
Nogle Aar senere bragtes Biskoppen paa Grund af et udsendt Hyrdebrev i Beraring med en Person af ganske samme Støbning som Mogens Sommer. P. P. Schmidt var et Uro, som ikke kunde tilfredsstilles af sin Skolegerning alene. Han maatte vidne om, hvad der var blevet hans levende Erfaring og klippefaste Overbevisning, og denne Overbevisning stemmede ikke overens med Sognepræstens. Saa blev det altsaa til Strid og Fortrædelighed. Der var visse Øjeblikke, da den sidste stille Glæde syntes at skulle forlade Mjolden Præstegaard, saadan huserede den usalige Skolemester med den ærværdige Præst.

Men Præsten O. H. B. Bojsen var en Broder til Præsten i Vilstrup, Udgiver af "Budstikken«. Hvad var mere nærliggende og forlosende for den plagede Mand, end at søge Trost hos Broderen og faa det oplevede trykt i »Budstikken «.

Al Skuffelse, al Vrede og Harme, al Krænkethed og Foruret. tethed i Menneskets Bryst higer mod Tryksværten. Lige saa snart den beske Galde bliver iklædt dette fløjlsbløde Hylster og ser sig selv paa Tryk, saa linder det.

Anno 1858 var det. Da sendte Præsten i Mjolden til Præsten i Vilstrup, og Præsten i Vilstrup sendte til Bogtrykkeren, og Bogtrykkeren trykte i "Budstikken" følgende:

I flere Aar har en Seminarist Smidt holdt Friskole her i Sognet, med hvem jeg fra Begyndelsen har haft megen Strid ... indtil Begyndelse af sidste Aar, da var han maaske allerede ved Søren Kierkegaard, men dog mere afgjort ved Lammers i Norge, som han idelig paaberaaber sig, og ved hans Udtrædelse af Folkekirken, blevet fjendtligt stemt imod denne. (Spændingen blev saa stærk, at Præsten en Dag gav sine Konfirmander Valget imellem ham og Schmidt. Stor Bevægelse i Sognet. Præsten fortsætter:) Jeg havde imidlertid (lige som før) selv mange Bekymringer og maatte paany drage hele min præstelige Stilling her i Sognet og i Folkekirken ind under en ny Provelse og jeg led meget af Anfægtelse. Som Johannes i Evangeliet sendte Bud til Jesus, skikkede jeg selv saa inderligt Bud, fordi der var mig saa trangt om Hjertet. Men i Begyndelsen var alt det Svar, 
jeg fornam - dette: du er ikke som du skulde være, du har Uret. Det er galt fat med dig ... og jeg brast i Graad, saa min Kone, der sad inde i min Stue, maatte høre det. Da kon vi til at tale med hverandre derom og al hendes Trost slog jeg ned med - det er galt - jeg hører ikke andet fra Vorherre end dette: du har Uret, og saa blev vi tilsidst enige om, at jeg maatte give min Præstegerning op - og du kan nok tænke mig, vi var meget bedrøvede begge to.

Men ud paa Natten hørte Præsten Ordet: Jesus Kristus er vor Retfærdighed, og dermed faldt han til Ro.

Broderen gjorde ingen Bemærkninger til Sagen. Men Biskop J. Daugaard rørte ved den i sit Nytaarsbrev 1860 og kom her for Skade, at regne P. P. Schmidt til de selvkaldte Prædikanter og Profeter. Da skrev den unge Skolemester til den gamle Biskop med fin og fast Haand et Brev, som vidner om den Myndighed og Selvsikkerhed, der altid kendetegner Mænd, som lyder en Aand og tjener en Sag.

Han skrev: "Dersom jeg er en selvkaldet, og som saadan udfører en ulovlig Gerning, da maa jeg onske at blive overbevist derom; thi at trænge sig ind $i$ en fremmed Bestilling, er jkke alene en frugteslos Gerning, men en saadan ender desuden med Skam og Skade. Nødig vilde jeg bære min Byrde forgjæves; men frygteligere vilde det endda være, hvis jeg hos Herren skulde paadrage mig desto større Dom. Men som jeg nødig vilde paadrage mig et evigt Ansvar i Forhold til mine Medmennesker, saa vilde jeg ejheller, at De skulde paadrage Dem et Evigheds-Ansvar i Forhold til mig ved at forhaste Dem i Deres Bedømmelse over mig, ved at paahænge mig Ulveklæder og fore mig i Klasse med dem, som Jesus kalder Tyve og Røvevere. Paa Grund heraf fremkommer jeg for Deres Højærværdighed med det billige Forlangende, hvis Opfyldelse De og enhver Forstandig vil indrømme, er ikke andet end min Ret og Deres Pligt, dette, at De $i$ en Skrivelse privat eller offentlig grundig vil godtgjøre, at jeg fortjener at sættes blandt de selvkaldede Prædikanter og Profeter.

... har Præsterne Boisen, Christensen, Ussing, Hjort og 
Provst Bohr fundet Beroligelse i Deres givne Trost, er den falsk. Jeg fordrister mig til at give Dem (altsaa Biskoppen) den Formaning: Vogt Dem, at De ikke kommer til at stride imod Gud; vel er jeg $i$ en vis Forstand mindre end en Ubetydelighed mod Dem og Deres Embedsbrødre i de 170 Præste- eller Sognekald, dog desuagtet tør jeg forudsige Dem, at Kampen paa bibelsk Grund kan blive betænkelig nok her, endsige Udfaldet hisset.

... Iøvrigt tilbyder jeg Dem, naar De i tilstundende Sommer kommer her til Medolden til Visitats Afholdelse, i Deres Narværelse at holde et Foredrag over den guddommelige og den statskirkelige Kaldelse, hvoraf De da og vil erfare mine Grunde, hvorpaa jeg bygger min Ret til at forkynde Guds Vidnesbyrd. Desuden vil De og høre mit Forsvar med Hensyn til Opposition mod Kirkens (Statskirkens) beskikkede Lærere, som De og ved samme Lejlighed yderligere vil faa Ánledning til mundtlig at modsige mig, samt gendrive mig mine øvrige vildfarende Lwrdomme.«

Hvad skulde nu Jakob Daugaard gøre ved det? Han havde ingen Budstikke-Broder, som kunde lette Trykket ved Tryk.ing. Saa tog han Skrivelsen og lagde den til sin „private Korrespondance«, og der ligger den endnu i Dag. Jeg har haft den i min Haand og læst den og lagt den hen igen, hvor den raa. Men en lille Stund dvæler mine Tanker endnu ved Biskoppen og Skolelæreren og Præsten. Hvor har de taget saa forskelligt paa det ældgamle Spørgsmaal om, hvorledes et Menneske kommer tilrette med sin Gud, den ene med overlegen Kløgt og Livsvisdom, den anden med ubønhørlig Lidenskab, den tredie med stille dryppende Taarer.

Men vi skynder os afsted endnu længere sydpaa. Det lille, allerede omtalte Blad, "Brevbærer mellem Kristne" $i$ København melder 1856: "Ild i den sønderjydske Statskirke». Og det er her ikke saadan, som Aviserne ellers plejer at føje til, at Ildens Opkomst er uopklaret. Ildspaasætteren er Johannes Matthias Dahl, Arkediakonen ved Kristkirken i Tønder. Ogsaa denne Sag, som her nu skal belyses, hører hjemme i Aaret 1855, S. Kierkegaards Dødsaar. 
Vil man høre, hvad denne Ildspaasætter var for en Person, saa gor man bedst $i$ at Iæse det Eftermæle, som Kirkekalender for Slesvig Stift 1862 modtog fra en Skolelærer i Tønder.

J. M. Dahl var født i Fjaltring Præstegaard ved Lemvig. Allerede hans Barndom og Hjem i disse Egne vakker Minder om den Kierkegaardske Slægt. Faderen kaldes en trofast Præstemand, inderlig sammenvokset med sin fattige Menighed og fast besluttet paa ikke at forlade denne, skønt Kaldets Indtægter var yderst knappe.

Præstegaardshaven i $\mathrm{Fj}$. var dengang kun udstyret med en eneste, jeg ved ikke om det var Ribs- eller Stikkelsbærbusk, iøvrigt fandtes der nok hverken Gren eller Kvist. Men den Lyksalighed, som hin Busk hvert Foraar og sommer forskaffede den lille Johannes, kunde han som Mand næppe omtale uden en Taare $\mathrm{i} \emptyset$ jet, endskønt den aldrig drev det til at frembringe et eneste modent Bær. Selv Sjællands lyse og fyldige Bogeskove blegnede næsten for Mindet om Busken i Fjaltring. Saa blev da ogsaa St. St. Blicher hans kære Digter. Men efter en religiøs Opvækkelsestid i hans Studenterdage tog Søren Kierkegaard hans Sjæl fangen. Stormsignalerne i 1855 virkede som et elektrisk Stød paa ham. Han forstod, at han maatte med i Kampen, og han fik da ogsaa sin Part af Snerterne.

Det, der gav Anledning til, at Præsten tornede sammen med sine Foresatte, synes nu at være en ringe og ubetydelig Ting, som næppe i dette Aarhundrede vilde have draget alvorlige Følger efter sig; men dengang vejede man Ordene paa en anden Vægt. I en Søndagsprædiken udtalte Præsten sig om Statskirkens mangeBrøst og Bræk og anførte bl. a., de "ukristelige og ubarmhjertige Love, som følges i Kirke og Skole«. Det var nok. Provsten sad i Kirken og havde hørt det, kunde ikke tie dertil. Først lod han Præsten hente til en personlig Samtale med kærlig Advarsel. Saa sendte Provsten ham den Skrivelse paa Embedsvegne, som han mente sig forpligtet til, med Trusel om at en alvorlig Indskriden vilde gøres nødvendig, hvis Ytringer af den Art ikke undlodes i Fremtiden. J. M. Dahl krævede Bevis for, at han havde sagt Usandhed eller noget, som var stridende 
imod Skriften, og da der i Provstens Skrivelse slet ikke var rort ved denne Side af Sagen, erklærede Præsten den hele Skrivelse for død og magtesløs. Provsten tav og lod sig aldrig mere se i Gudstjenesten, naar Pastor J. Dahl prædikede, vistnok det klogeste, han kunde gøre.

Men i Amtmandsboligen i Tønder sad Grev Arthur Reventlow, som ikke mente, at der var Grund til Skaansel imod den ivrige Præst, og som formentlig heller ikke havde noget Begreb om, hvorledes aandelige Sager bedst haandteres. Samtiden lader ogsaa tydeligt nok forstaa, at Greven vilde Præsten til Livs.

Fra Amtmandens Haand kom Sagen til Ministeriet og gennem Biskoppen, U. S. Boesen i Flensborg tilbage til Præsten. Noget skulde der gøres, og det endte med, at J. M. Dahl maatte underskrive en af Ministeriet forelagt Forpligtelse til herefter at føje sig efter Landets Love.

Dette var det første Stykke af Striden. Akterne er af Præsten selv overladt til Dansk Kirketidende og trykt i Nr. 7, Aargang 1856.

Nu var der skudt paa Vildtet, og Jægeren tabte det ikke af Syne.

I $1859 \mathrm{kom}$ Præsten til at sige i en af Byens Skoler, at en Konfirmationshandling, som havde fundet Sted et Par Dage i Forvejen, ikke var andet end en Komedie. I det hele taget kunde han ikke forlige sig med den Maade at holde Konfirmation paa, som da brugtes, idet et Flertal af Børnene ikke kunde antages $i$ Sandhed at aflægge det Løfte, som krævedes af dem. Det var noget af det, som S. Kierkegaard kaldte: At holde Gud for Nar. Ogsaa denne Gang var det Amtmanden, der som Medlem af Kirkevisitatoriet indberettede til Ministeriet, og Følgen blev, at Præsten indtil videre sattes ud af Embedsvirksomhed (suspenderedes). Fra den 16. August 1859 indtil den 5. Februar 1861 maatte han se paa, at andre besørgede hans Tjeneste, medens Anklagen,' hvis Virkning ingen kunde vurdere, svavede over hans Hoved.

Over Hundrede Mænd i Tønder indgav til det slesvigske 
Ministerium Begæring on at faa deres Præst igen. Tre jævne Borgermænd rejste til Lyksborg for at tale med Kongen.

Den Kommission, som nedsattes til at undersøge Sagen, blev omsider færdig, og ved en Appellationsretsdom indsattes Præsten igen i alle sine Rettigheder og Pligter.

Men da var Vildtet allerede saaret til Døden. Eftermælet siger: "Det er blevet almindeligt antaget, at J. Dahl's Sygdom, der begyndte i Eftersommeren 1859, havde om ikke just ligefrem sin Grund, saa dog sin utvivlsomme Anledning i hans Sammenstød med Statskirken."

Hans Aand vedblev at være klar og hans Hjerte glad og gudhengiven, indtil Døden gjorde alt stille.

Ved Baaren stod hans Ven fra Mogeltonder, H. Chr. Sonne, og talte saaledes:

"Saa ligger han da her fældet, vor kære Broder og Ven; han har lagt sine Pile og Sværd og Bue ned og ligger her, ganske uden Bekymring og sover Dødens søde Søvn...

...og jeg staar her i denne Stund ikke som den, der vil trænge sig frem paa et fremmed Sted, end mindre $i$ en fremmed Bestilling, ej heller fordi jeg tiltror mig at kunne sætte ham et varigt Minde, men det er den Vennegerning, som den Afdøde selv har testamenteret mig, at jeg i denne Stund skulde staa nærmest ved hans Kiste....

Om' det tror jeg vi alle ville være'enige: han var en ualmindelig Mand, han var intet Hverdagsmenneske, og dette er den Ubillighed, som saa ofte er vist mod ham, at man dog har villet maale ham med Hverdagsmaalet, at man har lagt det Sædvanlige an som Regelen, hvorefter han og hans Færd skulde vurderes. Og det Ualmindelige hos ham var at han i en overordentlig Grad var en Personlighed, et udviklet Selv, der aldrig sfondte Bud til "de Andre for at høre Besked, men vidste hos sig selv, hvorledes Sagen stillede sig for ham .... han hørte til de $\mathrm{i}$ en vis Forstand ulykkelige Mennesker, der $\mathrm{i}$ det Mindste ere satte i en strengere Skole end Andre, for de saa mere end de, gjennemskue dette Taageslør over Livet, som udgør den velgørende Synsgrændse for de Fleste .... Han blev dømt haardt 
af mange, men af mange, som ikke var værd at løse hans Skotvinge, han blev domt strengt af mange, men af Ingen saa strengt som af sig selv«. - -

Saadan talte Vennen. Men Biskoppen over Slesvig Stift, Ulrich Sechmann Boesen - havde han intet at sige, intet at meddele, intet at udtale over denne Grav? Og Provsten i Tønder, Hr. Odin Wolff Tidemand - traadte han ikke frem af Rækkerne, mens man stod omkring Graven, og krævede Ordet, selv om den Hedengangne ikke havde forlangt. det? Og Amtmanden, Greve Arthur Reventlow - gik han frem og sænkede sin adelige Kaarde over det nedlagte Edelvildt?

Vi faar ikke Svar og venter ikke paa Svar. Men der var en anden Mand i Tonder, et Slags Uvedkommende, Kaptajn Turah, Lærer ved Seminariet - ham maa det vel have været - som i de Dage skrev et Mindedigt over den hensovede Præst, hvis sidste Vers lød:

Der straaler en Blomst i Guds Urtehed,

den Blomst er du;

før havde du Trængsel, nu har du Fred, selv for Dødens Gru.

Tak, Hr. Kaptajn!

Mens vore Tanker saaledes dvælede en Stund ved det:Sidstoplevede, og vi saa os om efter en Blomst at lægge paa den nye Grav, er han, som talte ved Baaren, staaet paa sin Vogn og kørt ud ad Møgeltøndervejen. Vi følger efter ham, dels for hans Tales Skyld, dels for det Navns Skyld, som ved ham selv og hans dygtige Sønner er blevet kendt og æret i Danmark.

Hans Christian Sonne var født paa Bornholm og havde noget af den Helstøbthed over sig, som ofte har kendetegnet Folk fra denne $\varnothing$, ikke mindst i deres Forhold til Fædrelandet. Han kom som Præst til Møgeltønder 1845 og drog frivilligt bort i 1864. Efter sin Bortgang fra Hertugdømmerne kom han med i Arbejderbevægelsen i Danmark. I Thisted, hvor han ogsaa blev Provst, flk han gennem en Række Moder, han holdt med Byens Arbejder- og Fiskerbefolkning, Trang til at optage et Arbejde for en Forbedring af de ubemidlede Klassers okonomiske Kaar, 
og Midlet til en saadan Forbedring mente han efter sit Kendskab til den Virksomhed, The Rochdale Pioneers havde udfoldet i England, at finde i Kooperationen (Samvirke). Det forste praktiske Resultat af hans Bestræbelser blev Oprettelsen af den første danske Brugsforening i Thisted 1866. (Da. biogr. Haandb.)

Lad os i Forbigaaende lægge Mærke til, at mange af S. Kierkegaards Venner, lige som han selv, havde meget tilovers for de smaa iblandt Menneskene, de fattige, dem uden Navn og Penge. Johannes Dahl i Tønder var mest afholdt og savnet paa Fattiggaarden, Johannes Fibiger i Haderslev havde sine kæreste Venner og bedste Forstaaere iblandt de Gamle paa Hospitalet. Mogens Sommer havde sin kæreste Gang i Fængslet.

I Møgeltønder Sogn er H. Chr. Sonne endnu et godt Navn, især iblandt den ældre Slægt. Min Fader og Moder blev begge konfirmerede af ham, og i mit Hjem omtaltes han stadigt med uskrømtet og uforandret Frbødighed.

Det er mit Haab, at jeg ved en anden Lejlighed maa kunne give et fyldigt Billede af denne Præst, saadan som han fortjener det. I Dag er det kun om hans Stilling til S. Kierkegaard at gore.

Allerede hans Venskab og Fortrolighed med Præsten i Tønder lader formode, at $\mathrm{H}$. Chr. Sonne havde Øre for $\mathrm{S}$. Kierkegaards Budskab. Hvem der med Opmærksomhed gennemlæser de Bøger, han udgav baade før og efter 1864, vil ogsaa snart høre dette Budskab, om end of te kun dxmpet, lige som langt borte fra.

Her vil jeg for Kortheds Skyld nøjes med at gengive et Brudstykke af et Brev, som han i Thisted skrev til en Redaktor under den oven omtalte Bevægelse blandt Arbejderne. Med Et staar Personen lyslevende for os, baade i sin Karakter og sine Anskuelser. Brevet er hans egenhændige Afskrift eller Genpart og er kommet til mit Kendskab gennem en af Sønnerne.

"En Ting maa enhver $M$ a $n$ d sige sig selv, at hvor vi have med en Sandhed at gøre, formaar vi intet i mod den; vi kunne nok staa den imod,'men Følgen bliver blot, at vi løber Panden i Stykker imod den, den staar lige urokkelig.... 
Arbejderforeningen er for mig en stor Sag .... saalænge man ikke kan finde paa nogen Maade at give alle arbejdsløse Mennesker passende Arbejde - og det er vistnok umuligt - er Arbejderforeningerne den eneste Udvej, og hvor meget jeg kunde onske for min egen personlige Bekvemmeligheds Skyld at unddrage mig den Sag og have Fred, saa er Sagen min Overmand og lader mig forstaa at den vil bruge mig, og saa tør jeg ikke forraade den, og jeg vilde i mine Øjne blive en Pjalt, hvis jeg af Menneskehensyn, hvorved der dog ikke udrettes eller opnaas det Allermindste, undlader paa Opfordring at udtale min Overbevisning .... Min Sag er det, at tjene Sandheden og ikke "Sandhed med Modifikation", thi det er omtrent ensbetydende med Løgn.

Til Slutning kan jeg ikke undlade her at afskrive en Udtalelse af en for 13 Aar siden afdød Mand, der hørte til Danmarks, maaske hele Verdens, dybeste, skarpeste og mest klartseende Tænkere:

Ingen Enkelt i vor Tid enten tør eller kan træde afgjørende op, handle af egen Overbevisning og tage Ansvaret paa sig, men Alt betinges af Øjeblikkets Stemning, Alt gjøres afhængigt af Flertallets Samtykke. Skaden derved er dobbelt: For det Forste maa den Sagkyndige finde sig $i$, at hans egentlige Hovedtanke, hans omhyggeligt gennemarbejdede Plan under Oppositioner og Diskussioner beklippes, beskæres og ved haardnakkede Indvendinger, delvise Andringer, imødekommende Tillæmpninger saaledes omkalfatres, at den langtfra at blive af een Støbning tværtimod bliver et Flikværk af uensartede Stykker en broget Sammensætning af ulige Mønster, mindre lig en Plan end et Lappetæppe .... (hvilket man forsøgte at gøre med Præstens Forslag i Arbejdersagen).... Dette er endog det allerværste, Ansvarligheden fordamper i Diskussionen, bortdunster i Komiteebetænkninger og Afstemninger, saa at det hele tilsidst kommer ud som Værk af en Maskine, et Slags anonymt Produkt fra Partiernes Drivhjul....

Virkeligheden kan lige saa lidt bruge den rene Sandhed som den rene Usandhed, den kræver en egen Blanding af Godt 
og Slet, af Redelighed og Uredelighed. Virkelighedens Karakter bliver i denne Forstand en klog Forfarenhed, en kløgtig beregnet K a rak t e r lø s h ed. Men den kløgtige Karakterløshed er sædelig Tvetydighed, en raffineret Underfundighed, der ikke aabenlyst angriber men listigt udhuler det Bestaaende. (Saa vidt S. K.).

Dette er et Alvorsord, som vor forhandlende, diskuterende, talende, snakkende og passiarende Tid trænger til at lægge sig paa Hjerte, at vi vogte os for hver især at være smaa, oftest overmaade smaa Broker af Mænd, der maa suppleres af en heel støttende Skare af «de Andre", men at vi maa lære hver især at være en heel Mand, der veed, hvad han vil, og har et højere Maal og en gyldigere Regel at gaa efter end Massens Afstemning, og tor vove paa egen Risiko at have en Overbevisning; kun heri er Alvor, alt Andet er Fjas og Ynkelighed."

Manden, der skrev dette Brev, om ham behøver jeg ikke at sige mere. Hans Skikkelse staar for os som mejslet i Marmor. Og han var værd at mejsles i Marmor.

Vilde vi endnu se os lidt om for at undersøge, hvad der maatte findes længere ned i Tiden, som kunde sættes i Forbindelse med det, der her er skildret, da siger det sig selv, at Aaret 1864 betød en Afbrydelse med lignende Virkning, som naar man afbryder en elektrisk Strøm. Alle de Mænd, hvis Navne møder os paa disse Blade, forsvandt efter den for Danmark ulykkelige Krig, for saa vidt de ikke allerede i Forvejen havde forladt Skuepladsen. De tyske og tyskdannede Embedsmænd, som traadte i Stedet, havde andet at tage Vare paa end at studere S. Kierkegaard.

Dog var der iblandt de Elever paa Haderslev Latinskole, som havde haft Joh. Fibiger til Lærer og vel ogsaa siddet under H. P. Kofoed-Hansens Prædikestol adskillige, som i den følgende Tid fik en Stilling i deres Hjemland, navnlig flere Præster. Iblandt dem var vistnok Peter Johannes Georg Emil Wacker den betydeligste. Han blev Forstander for Diakonissestiftelsen i Flensborg. Om ham ved jeg, at han under sine Studier i København blev stærkt paavirket af Prof. Rasmus Nielsen 
og gennem ham selvfølgeligt af $\mathrm{S}$. Kierkegaard. "Jeg lever $\mathrm{i}$ disse Ting«, udtalte han ved Lejlighed, og der var ogsaa $i$ hans Liv et Tidspunkt, da han sporede Lyst og Trang til at forlade Statskirken (hvilket han dog ikke gjorde).

Hvad de Bevægelser og Kampe, vi her har været Vidne til, betød i sig selv, hvad Nytte de var til, hvad Følger de havde, og hvordan disse Mennesker hvirvledes ind $i$ dem og kom igennem dem, om alt dette kan og vil jeg intet sige, men dette ene skal siges:

Alvor var det.

Næsten svært falder det mig at skilles fra dem, nu da jeg har tænkt deres Tanker og færdedes i deres Kreds en lille Tid; jeg kendte dem jo i Forvejen.

Emil Wacker, Johannes Matthias Dahl, Hans Christian Sonne, P. P. Schmidt, Valdemar Thisted, Hans .Peter KofoedHansen (Jean Pierre), Johannes Fibiger, Mogens Sommer, Peter Kristian Koch - naar disse Navne, et efter et, langsomt glider forbi mit indre Øje, da synes jeg ikke, jeg skal skamme mig ved at bekende om mig selv, at ogsaa jeg engang gik i Skole hos Søı 'n Kierkegaard og blev en af hans ringe Lærlinge. 